\title{
Lethal T cell immunodeficiency induced by chronic costimulation via CD27-CD70 interactions
}

Kiki Tesselaar, Ramon Arens, Gijs M.W. van Schijndel, Paul A. Baars, Martin A. van der Valk, Jannie Borst, Marinus H.J. van Oers and René A.W. van Lier

Nat. Immunol. 4, 49-54 (2003).

Panel labels in the legend to Figure 2 were incorrect. The corrected legend is printed below.

Figure 2. T cell cellularity and phenotype in CD70 Tg mice. Absolute numbers of $\mathrm{CD}^{+} \mathrm{T}$ cells in PLNs (a) and spleen (b) from WT and CD70 Tg mice aged 4, 8, 13 and 20 weeks were determined. T cell numbers were calculated by multiplying the number of mononuclear cells with the percentage of $\mathrm{CD}^{+} \mathrm{T}$ cells, as determined by flow cytometry. (c) Thymic cellularity was determined by counting lymphocyte numbers of WT and CD70 Tg mice at the indicated ages. Mean \pm s.d. data from four to six mice are shown. Differences between the mean values for WT and CD70 Tg at the indicated ages were considered significant ( $*$ ) if $P<0.05$ (by Student's $t$-tests). (d) Phenotypes of CD4 ${ }^{+}$and CD $8^{+}$ splenic $\mathrm{T}$ cells determined by flow cytometry. Naive $\mathrm{T}$ cells were defined as $\mathrm{CD} 44^{\text {neg/lo }} \mathrm{CD} 62 \mathrm{~L}^{\text {hi }}$; effector-memory cells were defined as $\mathrm{CD} 44^{\mathrm{hi}} \mathrm{CD} 62 \mathrm{~L}^{\mathrm{neg}}$. The percentages of cells in each quadrant are indicated.

corresponding author details:

Kiki Tesselaar

K_Tesselaar@CLB.nl

phone: 0031205123314

fax: 0031205123310 